\title{
Level of Zinc, Retinol, Blood Macrophages, T- Lymphocytes and Immunoglobulin $G$ in Children with Tuberculosis and Non Tuberculosis
}

\author{
Merryana Adriani ${ }^{1 *}$, Yoanita Indra Kumala Dewi ${ }^{2}$, Eva Inayatul Faiza ${ }^{3}$ and Bambang Wirjatmadi ${ }^{1}$
}

${ }^{1}$ Public Health Faculty, Airlangga University, Surabaya, Indonesia

${ }^{2}$ Nglegok Health Center, Nglegok, Blitar

${ }^{3}$ Kendedes Stikes, Malang

\begin{abstract}
Tuberculosis remains a major cause of morbidity and mortality in children in the world, but still lack of priority in overcomes them. Every year estimated 9 million new tuberculosis cases with 1 million of whom are children aged $<15$ years and 2 million of them died. Nutrients which are very influential on a child's immune system are fat, protein, vitamin A and zinc. The presence of zinc in the body greatly affects the immune function so it plays an important role in the prevention of infectious diseases, including tuberculosis. The purpose of this study is to determine differences in serum zinc levels, serum retinol levels, levels of blood macrophages, T-lymphocytes and IgG between children with tuberculosis with healthy children or non- tuberculosis.

This study is a comparative observational study with cross sectional study design. The sampling technique of this study was simple random sampling. This study was conducted at RSUD Sidoarjo with each 11 children in tuberculosis and non-tuberculosis group as a sample.

At the end of this study, it discovered that there are significant differences levels of zinc serum $(p=0.003)$, retinol serum $(p=0.018)$, blood macrophages $(p=0.001)$, T-lymphocytes $(p=0.001)$ and $\lg G(p=0.006)$ between tuberculosis and non-tuberculosis group. The levels of zinc, retinol and IgG on children with tuberculosis were lower than nontuberculosis children, but T-lymphocytes on children with tuberculosis were higher than non-tuberculosis children. It suggested for giving zinc and vitamin A regularly and appropriate dosing in children with tuberculosis where it is useful to improve the durability of the body and can improve the child's appetite.
\end{abstract}

Keywords: Zinc; Retinol; Macrophage; T-lymphocyte; Immunoglobulin G; Tuberculosis

\section{Introduction}

Tuberculosis remains a major cause of morbidity and mortality in children in the world, but still lack of priority in overcomes those [1]. Tuberculosis in children is still a public health problem in Indonesia as the country with the highest proportion of tuberculosis number 3 in the world after India (30\%) and China (15\%) with proportion $10 \%$.

Tuberculosis in children is a systemic disease [2]. Every year estimated 9 million new tuberculosis cases with 1 million of whom are children aged $<15$ years and 2 million of them died.

Nutrients besides needed for general purposes are also needed to maintain the immune system function properly. Nutrients which are very influential on a child's immune system are fat, protein, vitamin A and zinc. Zinc is required by various types of enzymes in carrying out its functions and plays an important role in the metabolism of the cellular level. The presence of zinc in the body also greatly affects the immune function so it plays an important role in the prevention of infectious diseases, including tuberculosis [3]. Zinc deficiency may result in the airway epithelial damage; interfere with the function of leukocytes, natural killer cells and complementary activity, making it easier for children suffering from infectious diseases [4].

Based on the results of previous studies, children with tuberculosis had lower plasma zinc levels compared with healthy children. Other studies have also found that children who experience poor nutritional status and low zinc levels in cases of pulmonary TB compared with children who do not have tuberculosis. These results prove that zinc provides an important role in the healing process of pulmonary tuberculosis because zinc may enhance the effects of tuberculosis medication after two months of therapy and serve as spur antitubercular immunological processes [5].
Data about differences in levels of serum zinc, retinol, blood macrophages, T- lymphocytes and IgG in the incidence of infections, especially tuberculosis, is still limited. Therefore, researchers wanted to determine differences in serum zinc levels, serum retinol levels, levels of blood macrophages, T-lymphocytes and IgG between children with tuberculosis with healthy children or non-tuberculosis.

\section{Methodology}

\section{Study design and population}

This study is a comparative observational study with cross sectional study design. The study was conducted at Sidoarjo local hospital, which is located in Sidoarjo city, Indonesia.

Population of this study was children aged 6-12 year old in study location. Eligibility criteria for sample were:

1. 6-12 years old when the study was conducted

2. Patients willing to participate in this study

3. No other minor to severe trauma or experienced surgery for the past few months.

*Corresponding author: Merryana Adriani, Public Health Faculty Airlangga University, Surabaya, Indonesia, Tel: 62081330151075; E-mail: anna_b_wirjatmadi@yahoo.com

Received March 27, 2015; Accepted July 06, 2015; Published July 11, 2015

Citation: Adriani M, Dewi YIK, Faiza El, Wirjatmadi B (2015) Level of Zinc Retinol, Blood Macrophages, T- Lymphocytes and Immunoglobulin G in Children with Tuberculosis and Non Tuberculosis. J Nutr Disorders Ther S1: 003. doi:10.4172/2161- 0509.S1-003

Copyright: @ 2015 Adriani M, et al. This is an open-access article distributed unde the terms of the Creative Commons Attribution License, which permits unrestricted use, distribution, and reproduction in any medium, provided the original author and source are credited. 
The children were examined on May until July 2013. Furthermore, the study sample was divided into groups of tuberculosis and non-tuberculosis, each 11 children. Children in tuberculosis group were confirmed with tuberculosis based on anamnesis and the result of physical examination and laboratory (Table 1).

\section{Informed consent and ethical clearance}

Informed consent was obtained from the parent or guardian of the children. Ethical clearance was given by the Public Health Faculty of Airlangga University. The authors had also presented the study to the ethical committee and had a certificate of ethical clearance from the ethical committee of the Public Health Faculty of Airlangga University.

\section{Data collection}

Data were collected through questionnaire-based interviews, anthropometric assessment and laboratory tests of blood samples.

\section{Anthropometric assessment}

Weight of children identified through anthropometric measurements using balance scales or "dacin".

\section{Dietetic assessment}

Information of dietary intake identified using 24-hours recall method. Information of dietary intake identified to know consumption level of fat, protein and zinc of respondents. To assist the subject in quantifying the food portion consumed, utensils were used.

\section{Biochemistry assessment}

Blood samples were collected by medical analyst to know level of serum retinol, serum zinc, blood macrophages, T-cell lymphocytes and IgG activity.

\section{Statistical analysis}

Processing and data analysis conducted using SPSS. Statistical tests used for analyze level of all variables study with ordinal data scale is Chi-square test with $\alpha=0.05$. A p-value $<0.05$ was considered statistically significant.

\section{Results}

Results of this study are observation of rates of protein, fat, carbohydrate and zinc consumption. Moreover the levels of serum zinc, serum retinol, blood macrophage, T-lymphocyte and Immunoglobulin $\mathrm{G}(\mathrm{IgG})$ were calculated.

\begin{tabular}{|c|c|c|c|}
\hline \multirow{2}{*}{ Variables Level } & \multicolumn{2}{|c|}{ Group } & \multirow{2}{*}{ p-value } \\
\cline { 2 - 3 } & Tuberculosis & Non-Tuberculosis & \\
\hline Protein consumption & $2.370 \pm 0.500$ & $3.270 \pm 0.790$ & 0.007 \\
\hline Fat consumption & $2.180 \pm 0.400$ & $3.360 \pm 0.810$ & 0.001 \\
\hline Carbohydrate consumption & $168.900 \pm 68.300$ & $255.500 \pm 144.060$ & 0.000 \\
\hline Zinc consumption & $2.550 \pm 0.930$ & $3.640 \pm 0.670$ & 0.009 \\
\hline Serum zinc & $1.270 \pm 0.470$ & $1.910 \pm 0.300$ & 0.003 \\
\hline Serum retinol & $1.550 \pm 1.930$ & $1.640 \pm 0.500$ & 0.018 \\
\hline Blood macrophage & $2.640 \pm 0.500$ & $1.640 \pm 0.500$ & 0.001 \\
\hline T-lymphocyte & $1.180 \pm 0.600$ & $2.180 \pm 0.600$ & 0.001 \\
\hline Immunoglobulin G & $1.909 \pm 0.301$ & $1.363 \pm 0.504$ & 0.006 \\
\hline
\end{tabular}

Table 1: Levels of all variables study in Tuberculosis and Non-Tuberculosis children in Sidoarjo local hospital 2013.

\section{Protein Consumption Rate}

The mean of protein consumption rate on tuberculosis group $(2.37 \pm 0.50)$ were lower than non-tuberculosis group $(3.27 \pm 0.79)$. There is a significant difference of protein consumption rate between tuberculosis and non-tuberculosis group based on Chi-square result $(\mathrm{p}=0.007)$.

\section{Fat consumption rate}

The mean of fat consumption rate on non-tuberculosis group $(3.36 \pm 0.81)$ were higher than tuberculosis group $(2.18 \pm 0.40)$. From Chi-square result, it is showed that there is a significant differences of fat consumption rate on respondents between tuberculosis and nontuberculosis group $(\mathrm{p}=0.001)$.

\section{Carbohydrate consumption rate}

The mean of carbohydrates consumption rate on non-tuberculosis group (255.50 \pm 144.06$)$ were higher than tuberculosis group (168.90 \pm 68.30). There is a significant difference of carbohydrates consumption rate between tuberculosis and non-tuberculosis group based on Chisquare result $(\mathrm{p}=0.000)$.

\section{Zinc consumption rate}

The mean of zinc consumption rate on tuberculosis group $(2.55 \pm$ $0.93)$ were lower than non-tuberculosis group (3.64 \pm 0.67$)$. From Chisquare result, it is showed that there is a significant difference of zinc consumption rate between tuberculosis and non-tuberculosis group $(\mathrm{p}=0.009)$

\section{Serum zinc level}

From the Chi-square result, there is a significant differences of serum zinc level on respondents between the two groups $(p=0.003)$. The mean of serum zinc level on non- tuberculosis group $(1.91 \pm 0.30)$ were higher than tuberculosis group $(1.27 \pm 0.47)$.

\section{Serum retinol levels}

From the Chi-square result, there is a significant differences of serum retinol level between tuberculosis and non-tuberculosis group $(\mathrm{p}=0.018)$. The mean of serum retinol level on non-tuberculosis group $(1.64 \pm 0.50)$ were higher than tuberculosis group (1.55 \pm 1.93$)$.

\section{Level of blood macrophages}

From the Chi-square result, there is a significant differences level of blood macrophages on respondents between the two groups $(\mathrm{p}=0.001)$. The mean of blood macrophages level on non-tuberculosis group (1.64 $\pm 0.50)$ were lower than tuberculosis group $(2.64 \pm 0.50)$.

\section{T-lymphocyte level}

From the Chi-square result, there is a significant differences of T-lymphocyte level between tuberculosis and non-tuberculosis group $(\mathrm{p}=0.001)$. The mean of T-lymphocyte level on non-tuberculosis group $(2.18 \pm 0.60)$ were higher than tuberculosis group $(1.18 \pm 0.60)$.

\section{Immunoglobulin G level}

From the Chi-square result, there is a significant differences of IgG level on respondents between the two groups $(\mathrm{p}=0.018)$. The mean of IgG level on non-tuberculosis group $(1.363 \pm 0.504)$ were lower than tuberculosis group $(1.909 \pm 0.301)$. 


\section{Discussion}

\section{Protein consumption rate}

Based on studies of Suryadi [2], the higher the protein intake which consumed by children with tuberculosis it would improve the nutritional status. The higher the intake of protein consumed by children with tuberculosis will affect the status of nutrition also effects on the healing.

Result of this study showed that the mean of protein consumption rate on tuberculosis group were lower than non-tuberculosis grouped. There is a significant difference of protein consumption rate between tuberculosis and non-tuberculosis group $(\mathrm{p}=0.007)$.

Protein as a source of essential amino acids are needed as the builder substances for the growth and formation of the serum or hemoglobin, enzymes, hormone and antibody, replacing damaged cells, keeping the acid alkaline balance body fluids and energy source [6]. The protein functions as an instrument T-carrying hemoglobin where hemoglobin transports oxygen in the muscles called myoglobin and then transported in the blood plasma by transferrin and stored in the liver as a complex with ferritin [7].

\section{Fat consumption rate}

The mean of fat consumption rate on non-tuberculosis group was higher than tuberculosis group and there is a significant differences of fat consumption rate on respondents between tuberculosis and nontuberculosis group $(\mathrm{p}=0.001)$. The increase of the body fat percentage at tuberculosis patient is early marker indicator which led to positive balance.

While healing tuberculosis acceleration need of improvement in other important indicators such as decreasing inflammatory, increasing immune response and synthesis immunity as a result of improving gene expression on cells (transcription and translation). Positive balances in these indicators were extremely determined by the protein balance of the body.

\section{Carbohydrate consumption rate}

The mean of carbohydrates consumption rate on non-tuberculosis group were higher than tuberculosis group. There is a significant difference of carbohydrates consumption rate between tuberculosis and non-tuberculosis group $(\mathrm{p}=0.000)$.

Carbohydrate is not following the rule of Recommended Dietary Allowance, but $55-65 \%$ total energy is from carbohydrate. Indonesian diet largest proportion is carbohydrate, so the largest source of energy obtained from carbohydrate. If the consumption of carbohydrate can follow these guidelines then 55-65\% energy will be fulfilled. To reach $100 \%$ of energy, it will need from protein and fat. But on the contrary, if the carbohydrate consumption were insufficient, generally protein will be force to be used as an energy source. This is certainly not a good thing because it would interfere with the main function of the protein as a builder of the body.

\section{Zinc consumption rate}

Result of this study showed that mean of zinc consumption rate on tuberculosis group was lower than non-tuberculosis group. There is a significant difference of zinc consumption rate between tuberculosis and non-tuberculosis group $(\mathrm{p}=0.009)$.

Basically children often consume nuts products such as tofu and tempeh, also kind of grains such as rice and wheat (bread). However, these plant foods have low zinc also contains phytic acid which is inhibits the absorption of zinc [6]. A low level of zinc consumption also can be due to the low intake of animal foods as a rich source of zinc.

According to Adhi [8], a decrease in the levels of zinc affects the body's immune system against infections. On the child's condition with low zinc levels, immunity will decrease marked with the high frequency of suffering disease especially of infectious diseases. Serum zinc concentration in humans will decreased if suffering from an infection that resulted in decreased endurance body. In addition, the shortage of zinc can cause a late growth and decreased of appetite [9].

\section{Serum zinc level}

Zinc is micro nutrients whose existence is absolutely needed by the body in a small proportion to preserve optimal life. Zinc concentration in serum or plasma is the most often used as a parameter for determining zinc level of patient, because it was easily to be done and it is quite accurate. Zinc is very important micronutrients, as an immune system modulator especially in cellular immune system role, and plays an important role on body response toward tuberculosis.

Zinc plays a role in immune system, from skin barrier until a profitable in the lymphocytes. Zinc is needed for the normal function development on non-specific immune cells such as neutrophil, natural killer cells, as well as the development of specific immune such as growth and development of T-lymphocytes.

From the statistical analysis result of this study, there is a significant differences of serum zinc level on respondents between the two groups $(\mathrm{p}=0.003)$. The mean of serum zinc level on non-tuberculosis group was higher than tuberculosis group.

Decreasing on zinc level index in the body can be influenced by some factor from the inside and outside body and assumed that they have an impact on vulnerability to infection and worsening to sepsis. A decreased zinc serum is happening in the early fever or the early activation of endotoxins from bacteria known with the acute phase response (2-4 days) [10].

The decreasing zinc levels can be quickly happening during the acute phase response by high fever, in response to metabolic infection associated with iron depleting in the blood, increased copper levels in the blood, and the increased selective protein plasma, mediated by cytokines that is produce by monocyte and macrophage due to reactivation infection response.

\section{Serum retinol level}

According to Subowo [11] lack of vitamin A will bring various effects to the immune system, because it is needed to keep the unity epithelial structure and function (together with vitamin C). Vitamin A known would be needed for the mitogenic response from T-lymphocytes and B-lymphocytes also for binding mitogen of cell membrane for them to easily proliferate and needed for the expressed glycoproteins synthesis in cells membrane. Synthesis of glycoprotein itself needing vitamin A.

From the statistical analysis result of this study, there is a significant differences of serum retinol between tuberculosis and non-tuberculosis group ( $\mathrm{p}=0.018$ ). The mean of serum retinol level on non-tuberculosis group were higher than tuberculosis group.

Lack of vitamin A can affect epithelial integrity which cause epithelial mucous membranes damage and in turn will disrupt the IgA formation that is important to membranes mucosa defense system. 
Citation: Adriani M, Dewi YIK, Faiza El, Wirjatmadi B (2015) Level of Zinc, Retinol, Blood Macrophages, T- Lymphocytes and Immunoglobulin G in Children with Tuberculosis and Non Tuberculosis. J Nutr Disorders Ther S1: 003. doi:10.4172/2161- 0509.S1-003

Lack of vitamin A also will cause thymus glands and spleen diminution, cause the depletion of lymphocyte [11].

\section{Level of blood macrophages}

The Macrophages or monocyte include $2-8 \%$ of leukocytes and protect the body against invading microbes. Although plays an important role in plays a defense, an over exaggerating activating of the macrophages and especially their ability to produce high levels intermediate oxygen reactivation and as inflammatory cytokine TNF- $\alpha$ makes the macrophages more known in a variety of a chronic inflammation [12]. High number of monocyte or the macrophages generally shows that there is a bacterial infection [13].

From the statistical analysis result of this study, there is a significant differences of blood macrophages on respondents between the two groups $(\mathrm{p}=0.001)$. The mean of blood macrophages level on nontuberculosis group were lower than tuberculosis group.

Higher number of the macrophages in children with tuberculosis because it has to be working hard against tuberculosis, more infections cause excessive production of macrophages. Even though the macrophages are produced more, but because most of the bacteria are able to live independently fully, tried to survive to rely on capsule (influence attachment), cell wall (influence digestion), and releasing exotoxin (which damage the phagocytes and other cells) [12], tuberculosis should be assisted with anti-tuberculosis drug, which is bactericide and it is very effective to germs because of their metabolic active ability (germs that are developing) and it is also bacteriostatic. This drug is also effective in intracellular and extra cell germs, which can diffused into the body system and the body fluid [14].

\section{T-lymphocyte level}

From the statistical analysis result of this study, there is a significant differences of T-lymphocyte level between tuberculosis and nontuberculosis group ( $\mathrm{p}=0.001$ ). The mean of T-lymphocyte level on nontuberculosis group was higher than tuberculosis group.

Lymphocyte cells have a role in immune system, especially against infections that attack into the cells of the body. The lymphocytes T4 (CD4) or often referred to as the Thelper lymphocytes has a major role to regulate body's immune system. T-cells are a primary mediator immune defense response against tuberculosis. In imunofenotipe, T-cells come from $\mathrm{T}$ helper lymphocyte, also called clusters of differentiation $4(\mathrm{CD} 4)$ because it has $\mathrm{CD} 4+$ molecule on the surface.

\section{Immunoglobulin G level}

From the statistical analysis result of this study, there is a significant differences of IgG level on respondents between the two groups $(p=0.018)$. The mean of IgG on non-tuberculosis group were lower than tuberculosis group.

The IgG response slowly on primary antigens, but has risen rapidly with a higher power at the second presentation [15]. The antibodies from IgG are showed more dominant during secondary antibody response. This indicates that IgG is more mature response antibodies. The IgG antibodies are stronger because of its small microbial size, so he can easily penetrate into the infected area [16-18].

\section{Conclusion}

The children with tuberculosis should be given regular and appropriate doses of zinc, because zinc can increase child's body endurance and will increase the appetite. The children with tuberculosis also should be given appropriate doses of vitamin $A$, where vitamin $A$ is also useful to increase their body endurance.

We also need to explain to the public about the role and the importance of both vitamin A and zinc in the process of healing and the prevention of tuberculosis. It will need counseling and socialization about tuberculosis in the community so they are able to understand and be able to prevent this disease.

\section{Limitation in this Study}

The limitation of the current study is that the number of subjects in the trial was small. We hope that our results will stimulate larger community.

\section{Acknowledgement}

We thank all the children, their parents, the medical doctor, nutritionists and staff of the Sidoarjo local hospital, Indonesia. We also thank Professor Tri Martiana, Dean of Public Health Faculty in Airlangga University. This study was supported by the Directorate General of Higher Education, Ministry of National Education, Republic of Indonesia.

\section{References}

1. Lemeshow S (1997) Besar Sampel Dalam Penelitian Kesehatan. Yogyakarta: Gajah Mada University Press Suryadi, Yuliani R. Praktek klinik Asuhan Keperawatan Pada Anak. Jakarta : Sagung Seto; 2001.

2. Fedriansyah, Nazir, Theodorus, Husin S (2011) Hubungan kadar seng dan vitamin A pada kejadian ISPA dan diare pada anak. Sari pediatri 241-246.

3. Febriantoro (2012) Hubungan penyakit TB dengan Zinc. Jurnal TB.

4. Gibson RS. Principle of Nutritional Assessment ( $2^{\text {nd }}$ edtn). Oxford University Press. New York; 2005.

5. Almatsier S (2003) Prinsip Dasar Ilmu Gzi. Jakarta:Gramedia Pustaka Utama.

6. Budiyanto AK (2001) Dasar-Dasar IImu Gizi. Malang:Universitas Muhamadiyah

7. Adhi KT, Wirjatmadi B, Adriani M (2010) Perbedaan Kadar Seng Serum dan Kadar CReactive Protein Pada Anak Balita dengan Kadar Serum Retinol Normal dan Tidak Normal.

8. Pudjiadi, Solihin (2001) IImu Gizi Klinis pada Anak. Edisi Keempat. Jakarta: The publisher faculty of Indonesia University.

9. Prasad AS (2008) Zinc in human health: effect of zinc on immune cells. Mol Med 14: 353-357.

10. Subowo (2010) Imunologi Klinik, CV Sagung Seto, Jakarta

11. Playfair J, Chain B. At A Glance Imunologi edisi kesembilan. Jakarta: Erlangga press; 2012.

12. Andy (2013) Tuberkulosis.

13. Rahjoe NN, Basir D, Makmuri MS, Kartasasmita CB, Penyunting (2007) Pedoman nasional tuberkulosis anak Edisi ke-2. Jakarta: UKK Respirologi PP Ikatan Dokter Anak Indonesiam 4-34.

14. Corwin EJ. Patofisiologi. Jakarta EGC 2001

15. Ermayani (2013) Zinc Immune.

16. Kartasasmita CB (2009) Epidemiologi Tuberkulosis. Sari pediatri 11: 124-129.

17. Sunarjo J (2007) Tuberkulosis pada Anak.

18. Suryadi, Yuliani R (2001) Praktek klinik Asuhan Keperawatan Pada Anak Jakarta. Sagung Seto. 